\title{
PRO-DAESH JIHADIST PROPAGANDA. A STUDY OF SOCIAL MEDIA AND VIDEO GAMES
}

\author{
Magdalena EL GHAMARI, PhD \\ Collegium Civitas, Warsaw, Poland \\ elghamari@op.pl
}

\begin{abstract}
The fight that Europe and the West must wage against jihadist terrorism will take some time, but if we live up to our values of integration and democracy, we will come out of it soon. As Giovanni Falcone, the Italian judge killed by the Mafia, once said about the Mafia: "It is a human phenomenon, and as all human phenomena has a start and an evolution, it will have also an end".

Jihadis have been using Twitter at least since 2010, with the Shabaab joining the site in December 2011, but never before to this extent. One early adapter of Twitter, the Afghan Taliban, began to establish their social media presence in December 2010, through which they issued brief bulletins about their actions and alerts for forthcoming communiqués. Many of the most prominent jihadi groups have followed the same path, including the Shabaab al-Mujahideen, the Islamic State of Iraq and the Levant (ISIL), and al-Qaeda in the Islamic Maghreb (AQIM). The content of these Twitter accounts has tended to closely mirror material released to jihadi forums. For example, the Afghan Taliban may post the text of a communiqué to their website, to a jihadi forum, and to the Twitter account of one of their spokesmen. Mirroring jihadi groups, elements of the online jihadi community have also migrated to social media sites, with prominent forums such as Shumukh al-Islam and Ansar al-Mujahideen English Forum creating Twitter accounts to publicise notable releases and discussions. Concurrently, many individual jihadis and jihadi supporters have joined Twitter, enthusiastically circulating propaganda among themselves and promoting it to potential recruits. Yet, the benefits conferred by social networking come with a substantial cost: social networking platforms can sow great confusion if known official accounts are deleted and re-established or if there are multiple accounts claiming to represent a specific jihadi group. In order to reach the new official accounts, followers must be able to distinguish
\end{abstract}


the legitimate social media accounts of jihadi groups from non-authenticated users, which is a level of ambiguity that is not found on jihadi forums.

Key words: propaganda, terrorism, ISIS, media, jihadist games

\section{Introduction}

\section{Problem situation}

In the last year, the IS strategic military campaign has taken over large swathes of Syria and Iraq at lightening speeds, taking its opponents by surprise. Its political and ideological campaign is equally aggressive; it has taken the Internet and social media by storm. IS has forced a sea change in the way we understand modern terrorism. IS has not eclipsed Al Qaeda, which is still very relevant and dangerous, but it has physically broken away from Al Qaeda's leadership. IS continues to profit from the roots of Al Qaeda's already highly developed communications strategy.

IS is different from other terrorist organisations of the past for a multitude of reasons: first, its construction of a pseudo state, an "Islamic Caliphate"; second, its ability to sustain itself economically by amassing greater riches than any terrorist organisation in the past; third, its globalist and apocalyptic ambitions and its heady millenarianism; and finally, its powerful social media campaign with a global following, which has to date attracted over 18,000 foreign fighters from over 90 countries. The focus of this paper is to analyse the scale of the IS Internet campaign. It will describe how IS has unleashed cyber jihad and how best to confront this extremely innovative form of terror. Finally, the paper will outline some of the best practices for meeting this new challenge on and offline.

As many studies have shown, self-radicalisation and self-recruitment via the Internet with little or no relation to the outside world is still an anomaly. However, the Internet can facilitate, intensify and accelerate the process of radicalisation. Open forums and chat rooms can act as an engine of transformation because they can help validate existing ideas and facilitate support from like-minded people. Extremists can amplify their message in real time and with a global reach. Today, jihadist and extremist sympathisers freely post videos, tutorials, 
and religious propaganda with the aim of recruiting, cultivating and solidifying online partisanship and brotherhood in order to conduct terror. Most of today's IS followers grew up with the Internet, and they live and socialise online. When online, terrorist sanctions help normalise risky behaviour and act as an echo chamber in which extreme ideas are accepted and encouraged.

Media, thanks to the events in Arab countries commonly called the "Arab Spring", has taken on a new role. They ceased to be merely an SCEM-exchange for pictures and messages with friends, but became punk-tem meetings revolutionaries. Through group and created profiles on Facebook, activists posted about peaceful protests, encouraging participation in them. The authorities belatedly caught with the scale. Preventive action was taken by the Egyptians cutting off the internet. Nevertheless, people took advantage of other opportunities. One of them was posting on Twitter through the specially launched hotline. Information published in the local media largely deviated from the facts, which was demonstrated through videos posted on the website YouTube. They showed differences between the propaganda television programmes and the actual events in the region.

Social networking sites have played an important role in integration and identifying the population. They allow the expression of personal views and values, and are not just a tool for entertainment. An exchange of views is permissible on a massive scale. The events in Tunisia and Egypt have revealed the important role of online forums. Not only young, embittered people taking part in demonstrations, but also political parties, religious groups and representatives of the older generation appear on the network. Use of blogs, websites and online communication moved part of the political discussion to the internet. The ability to comment on social networking sites makes the platform for interpersonal interaction bigger and stronger than ever, and impossible to achieve using traditional media. Information placed by politicians reached citizens in a direct way that was previously impossible. The Muslim Brotherhood's portal on Facebook and Twitter is only part of the political activity of the Brotherhood. 


\section{Subject and purpose of work}

In today's information age, we must recognise that the essential "key terrain" is the will of a host nation's population. This has been demonstrated by our troops in al-Anbar, Iraq, and permits us to gain the trust of skeptical populations, thus frustrating the enemy's efforts and suffocating their ideology. The main goal is to show what jihadist propaganda by Daesh looks like: viewing religion, culture as a propaganda system which can be understood using theories and principles developed.

\section{Materials and methods}

Cultural Anthropology has decided to focus a special virtual issue on the theme of "security." This cultural security issue uses collaborative research and discovery of literature to fully exploit social networks and open source material. Crossdisciplinary studies identify open-source materials and form social networks. Collaborative research of anthropologists and sociologists reveals historical trade routes. Research databases specialising in tracking the literature of particular fields enable the discovery of literature in disciplines that hold insights into the political and security value of artworks and antiquities.

The popularity and importance of mass media was not so obvious at the beginning of the protests. Many Tunisians, feared sharing material with their friends because of potential reprisals. Despite this initial fear, many citizens could follow the events through activists forming the core of the revolution. Facebook was not shut down by the authorities of the country. Those who did not have access to the information on the web had access to satellite television, such as Al Jazeera, France 24 and Al Arabiya. Tunisian authorities did their utmost to prevent the spread of information through web portals. The government used phishing to block online activists. Many people were arrested for their activities on the network. It does not, however, prevented residents from achieving their goals.

If we want to get a sense of what attracts westernised Muslims to ISIS, we could do worse than listen to one of its sympathisers, as opposed to its legion of opponents, 
who are liable to pathologise the group's appeal as an ideological contagion that infects the weak, instead of taking it seriously as a revolutionary movement that speaks to the young and the strong-minded.

Since the Islamic State announced, in June 2014, that it had re-established the caliphate, the group has mounted a concerted campaign aimed at expanding its presence and influence beyond Syria and Iraq. For sure, the caliphate has not been re-established by Daesh, but in previous times it was by other fundamentalist organisations.

IS declared the formation of wilayats (provinces) in Afghanistan/Pakistan, Algeria, the Caucasus region of Russia, Egypt, Libya, Saudi Arabia, Yemen, and West Africa, while carrying out attacks in several other countries in the surrounding regions. The group has also appealed to Muslims from across the globe to join its cause, with thousands of foreign fighters answering this call to arms.

Daesh has utilised its propaganda apparatus, one of the group's most effective tools, to facilitate its expansion into new theatres. In almost every country where IS has established a presence, the group has deployed a robust messaging campaign aimed at winning over potential allies-including regional jihadist groups, political Islamists, and local Sunnis-and intimidating adversaries. The Daesh propaganda apparatus has augmented the group's on-the-ground expansion efforts and amplified its capabilities, sometimes fuelling exaggerated perceptions of IS' strength in new theatres.

Just one of many examples, the Twitter user "Bint Emergent": an apparent ISIS fangirl and keen observer of the jihadist scene. (Bint Emergent has not disclosed her identity, or gender, but bint is an honorific Arabic word for girl or daughter; like umm-mother in Arabic-bint features prominently in the Twitter user names of female ISIS sympathisers.)

"Jihadists," she explains on her blog BintChaos, "look cool-like ninjas or video game warriors-gangsta and thuggish even-the opposition doesn't." She concedes that "There aren't a lot of jihadist 'poster-girls' displayed-they all wear niqab [face veil], but sometimes it's tastefully accessorized with an AK47 or a bomb belt." By contrast, "Team CVE [a reference to Countering Violent Extremism, or AngloAmerican counterterrorism entrepreneurs whose role, state- or self-appointed, is to challenge "extremist" narratives]," consists "mostly [of] middle-aged white 
guys with a smidgen of scared straight ex-mujtahid's [ex-jihadists] and a couple middle-aged women."

"Jihadis have cool weapons. And cool nasheeds [a cappella hymns]," she continues. They also have "young fiery imams that fight on the battlefield," whereas Team CVE "has ancient creaky dollar scholars..." Most importantly: Salafi-jihadism made being pious cool. It became cool to quote aya [verse] and study the Quran. And CVE has absolutely no defense against this. ... I love jihadi cant-dem, bait, preeing, binty, akhi [brother]... it's like Belter dialect in the Expanse. And it borrows from all languages-because jihad draws from all races and ethnicities. The voice of youth counterculture and revolution for an underclass. Like ghetto culture in the US-the inexorable evolution of cool.

Jihadists now look to Call of Duty, Grand Theft Auto and western action movies to help 'make terror popular' - and it's working. The user-generated modification, or 'mod' in video game parlance, is understood to reward users for killing Westerners and characters based on Syrian regime soldiers and the brave Kurdish Peshmerga fighters who have formed the most effective resistance against the terrorists in real life.

Daesh supporters have previously used popular video games Grand Theft Auto and Call of Duty in their sickening propaganda films. But jihadists are using it to recruit children and radicalise the vulnerable, giving it out for free on gaming forums to those declaring support for ISIS.

Twisted ISIS supporters are distributing a sickening video game that allows users to play the role of Islamic extremists on a mission to murder Westerners. Supporters of the terror group, which has brought rape and massacre to vast swathes of Syria and Iraq, have modified the popular video game ARMA III to create characters based on ISIS militants. According to the website, one ISIS supporter took to a well-known pro-terror web forum to promote the mod, posting: 'In the latest version of the game ARMA III there are mods in which a user can play as an ISIS militant, especially against the Peshmerga and Syrian army.' A second anonymous supporter replied: 'I will, with the help of Allah, make dozens of copies for this game and distribute it for free to all the brothers that use the name of the Islamic Caliphate.' It is not the first time ISIS has hijacked Western video games to spread 
propaganda, having previously used Grand Theft Auto 5 to recruit children and radicalise the vulnerable.

Last September, ISIS uploaded a video to YouTube that carried the group's chilling black jihadi flag and showed violent scenes from the game - including police officers being gunned down and lorries being blown up by suicide bombers. At the start of the video, a message appears that reads: 'Your games which are producing from you, we do the same actions in the battlefields (sic)!!'. As the video continues, the players can be heard chanting Islamist slogans whenever a bomb explodes or another character is killed.

Pro-jihadi music is also heard playing throughout the video, which is designed to look and sound like the terror group's real-life footage of brutal slaughter that it has filmed in Syria and Iraq. ISIS has also made continual references to the hugely popular Call of Duty, producing slick posters that adopt the video games title to refer to jihad.

They have even produced slick propaganda films that ape Call of Duty's gameplay, using HD helmet cameras, freeze frame footage and heavily edited audio to make the terrorists' real-life murder and massacre in the Syrian city of Kobane look like little more than a video game.

A since deleted Twitter account by Islamic State sympathiser Abu al Abdel promises that the "Islamic State lions" will attack the Olympic games in Rio de Janeiro, Brazil. Yesterday, Islamic State terrorist channels on the encrypted messaging app Telegram were reminding would-be jihadists that it was the opening ceremony of the 2016 Rio Olympic Games. Rita Katz, founder of Site Intel, reports that Islamic State is instructing its followers on how to attack the games. Katz further reports that ISIS is telling jihadists to become "lone wolves" and "obtain guns or cause traffic accidents" and to attack public transit, take hostages, and to stab or poison people. 


\section{CALL OF JIHAD - The scope of the challenge}

In the modern world, one of the fundamental guarantees of success of the political, economic or social quick access to information. The role of different kinds of messages has become one of the key aspects of the activities of terrorist groups. These activities are increasingly asymmetrical, making the state anti-terrorist coalition unable to catch up with them, because they are not detected. Media, thanks to the rapid development of information and technological advances, has become a strong entity for influencing global reality. Modern communications technology, satellite broadcasting, GPS, internet and the constant quest for the freshest information, means that the media can be found in the centre of each potentially important or interesting event. It is also quite true that the media live exclusively sensationally. Although the most interesting thing for them is what stirs emotions, fear, terror, or outrage. This is because of two important reasons. On the one hand, purely economic motives, on the other hand, psychosocial. Rival journalism has been transformed into a race that has no end and it is completely understandable and natural. Most people are looking for today in the new media, and "strong" information. Stations which first receive shocking information, show the bloody recordings and occupy a place of honour in the forefront of the most watched television stations. In addition, the modern role and the importance of the media is closely linked with the democratic system. Media freedom and pluralism that are currently guaranteed constitutionally are the greatest achievements of democracy. Free media is an essential canon of civil liberties. The Islamic State's video recruiting campaigns have become increasingly sophisticated, and they're one reason it's able to attract new followers and galvanise them to bloody terror.

This video shows how ISIL's propaganda often nods to-and sometimes directly copies-memes, characters, and scenes contained in Hollywood movies, video games, and music videos. Think American Sniper or Hunger Games, and Grand Theft Auto or Call of Duty. By appropriating popular western culture, ISIL engages directly with its target audiences. It makes terror seem glamorous, and the victims of terror, actors in a western movie or game.

Javier Lesaca, visiting scholar at the George Washington University's School of Media and Public Affairs - analysed 845 videos that ISIL published between January 2014 and September 2015. He found that 15\% were inspired by real 
western movies and video games. ISIL's video recruiting effort is a marketing campaign on a massive scale. It's something no other terror group has done.

So-called Islamic State (ISIS) has emerged in less than two years as one of the major security challenges for the global community. At the same time, this terrorist group has become one of the most important phenomena in digital public communication since the beginning of the century. In fact, analysis of the digital audiovisual campaigns released by ISIS since January 2014 suggests that ISIS has established a new kind of terrorism, using marketing and digital communication tools not only for "socializing terror" through public opinion as previous terrorist groups did, but also for making terror popular, desirable, and imitable. This new phenomenon of unpredictable consequences could be described as "marketing terrorism."

It is perfectly understandable that United Nations has expressed its "grave concern at the increase of foreign fighters joining the Islamic State in Iraq and the Levant/ Sham". According to UN estimates, over 25,000 foreign citizens from more than 100 countries have joined ISIS and other branches. The secretary general of the UN also confirmed, on May 29, that there has been an estimated 70 percent increase in foreign terrorist fighters worldwide between the middle of 2014 and March 2015.

There is no single, simple answer to explain the growth of admiration and attraction that young citizens all around the world feel about joining international terrorism. But trying to understand this phenomenon from the perspective of public communication may provide some clues.

ISIS is following an unprecedented and sophisticated audiovisual strategy, consisting on the massive elaboration and distribution of audiovisual images that are highly salient and resonant in the culture of their targeted audiences.

ISIS's audiovisual campaigning is massive in scale. According to the data I have analysed, the terrorist group released 845 audiovisual campaigns between January 2014 and September 16, 2015, or more than one every day for a year and a half. The magnitude of these campaigns can be seen in their distribution. According to Brooking Institution research, ISIS supporters control more than 46,000 Twitter accounts, through which they release their messages directly to the smartphones of their audiences, avoiding the mediation of gatekeepers in traditional media. 
More importantly, these images released through social media are charged with images directly inspired by the modern culture of a young global audience. Qualitative analysis of all 845 campaigns shows that more than 15 percent are directly inspired by real films, videogames and music video clips of contemporary popular culture, such as the films:

- Saw,

- The Matrix,

- American Sniper,

- Vfor Vendetta;

or videogames like:

- Call of Duty,

- GTA,

- Mortal Combat X

- Grand Theft Auto.

The terrorist group uses cultural images of modernity in order to promote a political project based on anti-modern values.

In the case of ISIS videos showing executions, 40 percent feature highly salient cultural images. By doing this, ISIS transforms victims of terrorism into actors in Western popular cultural products, aimed at engaging with their global audiences and making terror popular.

In addition to the magnitude and the cultural resonance of the images, ISIS also employs another powerful marketing tool to reach public opinion: segmentation. The terrorist group has created a net of 29 audiovisual producers: three of them create products aimed at a global audience (for example: Al Furqan, Al Ittissam, and Al Hayat), and the other 26 create specific cultural products for each region controlled by ISIS in Syria, Iraq, Egypt, Libya, Yemen, West Africa, and Afghanistan.

In a blog post titled "Embracing Apocalypse I: the Islamic State and the Prophetic Methodology", women expresses particular admiration for a black-and-white photo of a Daesh fighter on the streets of Kobani in Syria. He is nonchalantly holding a machine gun, with an arm raised triumphantly in the air. Behind him is a scene of utter devastation, in which orange flames-the only colour in the photo-and thick smoke cascade from a truck and building. The fighter depicted 
is reportedly Abu Ahmad al-Tunisi. "This iconic photo," she writes, "distills the whole conflict into one image for me. To glory in apocalypse, to embrace it..." It also distills a possible contradiction or discrepancy: Abu Ahmad al-Tunisi is wearing, in addition to a thick, righteous beard, what appear to be a pair of Nike trainers. Nike is a large American corporation, and the distinctive Nike swoosh is a symbol of American urban cool-or, at least, it used to be. Apocalypse, Bint Emergent goes on to say, unconvincingly, is "a wholly alien concept for the west." But the idea of the righteous, brand-wearing badass certainly isn't.

The segmentation of Daesh messages also includes the use of different languages, depending on the audiences they try to reach with each message. ISIS has released 120 campaigns aimed at Western countries: 27 percent of those have been released in English, 15 percent in Russian, 13 percent in French, and 3 percent in German.

The ISIS communication strategy poses a new challenge in the fight against terrorism. For the first time in modern history, a terrorist group is talking directly to its target audiences on a daily basis in their own mother tongue, and in their own cultural language.

Counterterrorism efforts should also be adapted to this new field. Winning the hearts and minds of young generations all around the world is going to be a digital and communicational struggle that democracies cannot afford to lose.

\section{Gta Jihad video game trailer}

Islamic State (IS) militants have released a jihadist video game trailer in which the aim is to destroy Iraqi and US forces, Arabic media report. The game, styling itself as a Grand Theft Auto adaptation, appears specifically aimed at young people.

The recruitment propaganda video trailer aimed to "raise the morale of the mujahedin and to train children and youth how to battle the West and to strike terror into the hearts of those who oppose the Islamic State," according to the media wing of the IS (formerly known as ISIS), cited in Arabic media. "The content includes all of the organization's military tactics against its opponents," the Islamic 
state said. The video is loaded with explosions, combat scenarios and sniping, with jihadist calls being made throughout. Characters let out cries of "Allahu Akbar!" and - as is the case in real life - the characters slaughter and behead their victims and blow up vehicles.

Throughout, the IS logo is displayed at the top of the screen, alongside the apparent 'GTA' styling. Pervasive themes include jihad and "the willingness to sacrifice."

However, the video appears to be just that - merely a trailer, and an actual playable version of the possible game has not been seen. It was released shortly after new propaganda footage entitled 'Flames of War', which unfolds in a similar but moviestyle vein. Filled with blasts, it was considered a response to President Obama's declaration that he would "degrade and ultimately destroy" it. It appears to suggest that IS would annihilate any US ground forces that attempted to subdue it. It was released shortly after General Martin Dempsey, chairman of the Joint Chiefs of Staff, said at a Senate hearing that American ground troops may be required in the struggle against IS. "Flames of War" appears at the end of the trailer, with the tagline: "Fighting has just begun".

\section{Grand Theft Auto - islamic state 'virtual jihad'}

Executions in the streets, gun-battles against American special forces - a 'virtual jihad' has been launched by the Islamic State through a popular video game. Grand Theft Auto: San Andreas, a 2004 game which sold more than 27 million copies worldwide, has been filtered through the hands of Islamic State (also known as ISIS, ISIL, IS) propagandists to set the scene of its holy Sunni warriors waging war against the world.

Given the title Grand Theft Auto: Salil al-Sawarem (sound of swords clashing), the first-person "shooter" game is reportedly being promoted by the Islamic State to "raise the morale of the mujahidin and to train children and youth how to battle the West and to strike terror into the hearts of those who oppose the Islamic State." 
Players adopt the character of a bandanna-clad jihadist fighter wearing the group's iconic black shirt and camo pants. The battlefield is a barren landscape, strewn with rubble, wreckage and rocks. Targets include police, army convoys and patrols. The assault rifle comes as standard, as does the black-and-white Islamic State battle flag. The YouTube video trailer's fervent message is clear: Through self-sacrifice and righteous faith, America's attempt to "degrade and destroy" the Islamic State would be overwhelmed. The "easy and consequence-free" video trailer, released late last week, was aimed at a young audience. "What I also fear aside from the terrifying consequences of what this video could do, is the media barking up the 'video games are wrong for children' chant once again," he said.

\section{The power of propaganda magazine Dabiq}

Dabiq, as it is called, bills itself as "a periodical magazine focusing on the issues oftawhid (unity), manhaj (truth seeking), hijrah (migration), jihad (holy war) and jama'ah (community). It also contains photo reports, current events, and informative articles on matters relating to the Islamic State." It portrays the Islamic State as they see themselves: boasting of their victories and painting a romantic image of the restoration of an Islamic golden age and the heralding of a "glorious" new caliphate based on holy war.

Dabiq is a place in Syria that is supposed to be the location for one of the final battles according to certain Muslim myths about a final apocalypse. Choosing such a name for the magazine highlights the caliphate's goals.

The first issue of Dabiq, "The Return of Khilafah" is focused on the declaration of the caliphate and what that means. Some of the ideology behind the group is explained in an attempt to persuade more Muslims to join. It also explains the name of the magazine, and boasts of ISIS' victories. It also talks about efforts made to build support among local tribal groups, reporting their pledges of loyalty to Abu Bakr al-Baghadi, the self-appointed caliph of the Islamic State.

The second issue of Dabiq, "The Flood," uses the metaphor of the story of Noah to put across a stark message: you are either with the Islamic State or against them and doomed to be destroyed. It calls on all Muslims around the world to 
pledge loyalty to the Islamic State and to move there immediately. There is also a section on the attempts to resolve the disputes between the Islamic State and other Jihadi factions such as Jabhat al-Nusra by means of mubahalah, an Islamic religious arbitration process.

The third issue of Dabiq, "The Call to Hijrah" focuses on the jihadists' call to Muslims worldwide to move to Iraq and Syria to join the caliphate as soon as possible. Hijrah is Arabic for 'migration' and refers to the journey of the founder of Islam, Mohammed, and his companions from Mecca to Medinah in 622 C.E. The comparison is very deliberate and intended to invoke religious nostalgia.

The fourth issue of Dabiq is entitled "The Failed Crusade." It focuses on the attempts by the U.S.-led coalition to counter the Islamic State and mocks what the Islamists regard as a campaign doomed to fail. They express their certainty saying "This religion is the one promised with victory." The picture on the cover is of the iconic St. Peter's Square in Rome, displaying the group's ambitions of world conquest.

The fifth issue of Dabiq is named after the Islamic State slogan, 'Remaining and Expanding.' In this theme, it announces the expansion of the Islamic State into Sinai, Libya, Yemen, Algeria and the Arabian Peninsula after accepting pledges of loyalty (bay'ah) from terrorist groups there. It also announces the minting of gold dinars and silver dirhams in order to separate it from the international fiat currency markets and build the economy of the Islamist state.

The sixth issue of Dabiq is called "Al-Qa'idah of Waziristan: A Testimony From Within." This issue begins by taking responsibility for the terrorist attack in Sydney that killed two at St. Martin's Place and again calls on the Islamic State's supporters worldwide to carry out killings of Westerners whenever and wherever they can without revealing their intentions by discussing them. Most of the rest of the magazine focuses on internal jihadi disputes, criticising the Islamic State's detractors from within the jihadi movement.

The seventh issue of the Islamic State's Dabiq magazine is entitled From Hypocrisy to Apostasy. It begins with a declaration of war against Japan. Dabiq then boasts about the murder of the Jordanian pilot by immolation, before going on to give advice for would be leaders within the Islamic State. It reiterates their commitments to war, arguing that "Islam is the religion of the sword." It then proceeds to tout its 
successes in Egypt and Libya. It reiterates its division of the world into two camps and includes interviews with jihadists and hostage John Cantlie.

The eighth issue of the Islamic State's Dabiq magazine is called Shari'ah Alone Will Rule Africa. Like other issues of Dabiq, it focuses on Islamic State successes, leaving out the group's defeats in strategic areas of Iraq and Syria to focus on Africa. It emphasises the pledge of allegiance from Boko Haram in Nigeria and terror attacks in Libya and Tunisia. It tries to portray an organisation with a future by glorifying its child soldier programme and undermining the legitimacy of Al-Qaeda affiliat Jabhat al-Nusra by attacking its allies as 'nationalists' and, therefore, un-Islamic.

The ninth issue of the Islamic State's Dabiq magazine is called They Plot and Allah Plots, referring to the central feature of the magazine which argues that Islamic State supporters should not fear any plans to defeat them since Allah controls the world. The issue focuses on legitimacy - both attacking that of its enemies in Syria and the surrounding Arab nations, and in building up its own, with pieces on the importance of jihad. Most shockingly, this issue ran a lengthy segment admitting to and justifying sex slavery. It threatens to sell US first Lady Michelle Obama into sexual slavery for a third of a dinar.

The tenth issue of the Islamic State's Dabiq magazine is called The Laws of All or the Laws of Men. It opened by praising the deadly simultaneous terror attacks in Tunisia, Kuwait and France and the massive casualties caused. It calls on children to obey Allah (i.e. ISIS) before their parents and wives to leave their husbands who fight ISIS. It also boasts of expansion in the Caucasus and recruitment in Afghanistan. Since it is the Ramadan issue, it discusses the historical victories of some of the early Muslim armies during Ramadan as well as expounding on the holiness of the month.

The eleventh issue of the Islamic State's propaganda magazine is called From the Battle of Al-Ahzab to the War of Coalitions. Al-Ahzab refers to a battle in theQuran between a coalition of Meccan tribes and the nascent forces of Islam. ISIS attacks al-Qaeda and castigates the Taliban for concealing the death of Mullah Omar. ISIS also accuses the Shiite messiah (Mahdi) of being the dajjal (devil) in league with the Jews. More is directed at women, who are urged to have children and care for their jihadi husbands. ISIS also tout their establishment of gold dinars as currency and boast of having captured a Norwegian and a Chinese hostage, who are offered up for ransom in full page adverts. 
The twelfth issue of the Islamic State's propaganda magazine is entitled Just Terror. It boasts about the terrorist attacks in Paris, the double-bombing in Beirut, and the downing of a Russian plane in Sinai, among other attacks. It spins terrorism in the language of a fairy story, referring to terrorists as "knights," acting to defend Muslim honour. This issue is also striking for the high number of Islamic State propaganda videos it advertises, a sign of increased output in that area. Other pieces continue long-running themes, including attacking the legitimacy of other Islamist factions, recounting its military victories and attacking women who oppose polygyny as opposing Islam.

The thirteenth issue of the Islamic State's propaganda magazine is called The Rafidah: From Ibn Sa'ba to the Dajjal. Rafidah is a pejorative term for Shi'ite while the Dajjal is an antichrist figure in Muslim eschatology. The magazine opens by praising the San Bernardino attacks which killed 14 people in California. It goes on to attack Saudi Arabia's legitimacy and heavily criticise the history of Shiite Islam in Iran. Jihadi John received a full two page obituary in the recurring section 'Among the Believers are Men' and the 'To Our Sisters' section provides advice on the correct way to mourn a martyred husband.

Issue fourteen of the Islamic State's magazine is entitled The Murtadd Brotherhood, referring to the Egyptian Islamist group, the Muslim Brotherhood, as apostates. In addition to sections praising the terrorists who carried out the attack on Brussels airport on March 22, Dabiq features a section attacking the legitimacy of the Muslim Brotherhood. It also exhorts ISIS supporters to kill a slew of Muslim leaders living in the West, some of whom are linked to the Brotherhood or hold Islamist views. Regular features boasting of alleged military victories, praising departed fighters and advertising ISIS videos are also included.

The fifteenth issue of the Islamic State's Dabiq magazine is called Breaking the Cross and is targeted at discrediting Christianity and Western secularism. Unlike previous issues which have primarily been directed at Muslim majority societies, this issue is full of propaganda aimed at converting non-Muslims to Islam. Sections include "Why we hate you and fight you" along with a conversion story "Why I came to Islam" from a former Christian woman from Finland. The main feature "Breaking the Cross" is an extended rebuttal of Christian and Jewish theology which sets forth the arguments to believe in Islam. 


\section{Conclusions}

Parts of the Middle East and Africa are sliding towards a warlord era. States are struggling to control their territory. Parts of states are now under the rule of local chiefs, rebel groups and terrorist movements. Armed irregular forces are holding effective power over growing areas of Iraq, Libya, Mali, Nigeria, Somalia, Syria, and Yemen. Motivated by extreme forms of militant Islam or regional separatism, non-state actors have grabbed territory and are creating their own version of law and order.

Karl Marx said, that "Religious suffering is at the same time the expression of real suffering and a protest against real suffering. Religion is the sigh of the oppressed creature, the heart of a heartless world, the soul of soulless conditions. Religion is the opium of the people".

ISIS propaganda imbues the idea of jihad not only with traditional notions, but also a strong undercurrent of postmodern cool.

The cross-cultural appeal of this figure is hard to deny, as Richard E. Nisbett and Dov Cohen make clear in their study Culture of Honor: "The world over, men are sent out to sacrifice and to die, not for such purely instrumental purposes as deterrence; rather they are motivated by what they and the community expect good, honorable men to do". "There is," indeed, Nisbett and Cohen remark, "a romance and an allure to the Masai warrior, the Druze tribesman, the Sioux Indian, the Scottish chieftain..."

For those who are bewitched by it, there is also a romance and an allure to the jihadist warrior. In a recent article, "The Soft Power of Militant Jihad," the terrorism expert Thomas Hegghammer touches on this and the wider "jihadi culture" of fashion, music, poetry, and dream interpretation. "Jihadis," he writes, "can't seem to get enough anashid [nasheeds]. They listen to them in their dorms and in their cars, sing them in training camps and in the trenches, and discuss them on Twitter and Facebook." "Jihadi culture," he elaborates, "also comes with its own sartorial styles. In Europe, radicals sometimes wear a combination of sneakers, a Middle Eastern or Pakistani gown and a combat jacket on top. It's a style that perhaps reflects their urban roots, Muslim identity and militant sympathies." Hegghammer concludes that "as the West comes to terms with a new and growing threat ... we 
are not only confronting organisations and doctrines, but also a highly seductive subculture."

The essence of the activities of Islamic fundamentalists, that is, attack a person or group of people, does not have a significant impact on the achievement of the objectives set by them. Measures with a terrorist character must therefore be guided by a significant psychological effect, noise and social media. Only then can the act of terror be effective. Key aspects of Islamic fundamentalism are fear and insecurity, the threat of support action or direct action by extremists. In addition, victims of today's attacks, specific individuals are the least important, but only the quantity counts. Fundamentalists recognise the principle that the more bloody the coup, the more fear and terror. Its effects are, thus, psychologically strong to a wide audience. Islamic fundamentalists, including all groups of Al-Qaeda, are guided by these principles. Their goal is to kill not so many people. In this way, they triggered reactions that paralyze and prevent the functioning of entire societies. All these mechanisms work regardless of whether it comes to the actual use of force, or the mere threat of using it. Fear takes the dimension of the individual and the collective. To initiate the process to influence the psychological factor, fundamentalists only need to carry out a successful attack or series of attacks. Through these actions they have to authenticate themselves and their "case". The mechanism of such action occurs frequently under a classic scheme:

- An attack on an often random target

- Disclosure, by means of the media (the granting of an act, mentioning the name of the organisation which carried out the attack, presenting the motives and objectives of the action)

- Re-formulation of menacing attack,

- Make demands and conditions that will not cause further attacks.

- Information that failure to meet demands will entail further attacks.

Islamic State (IS) has a sophisticated and effective communication strategy that uses online media tools to disseminate its multidimensional propaganda. It has populated social media platforms and has attracted a global network of supporters that articulate, magnify and circulate its violent extremist messages worldwide.

The genius of ISIS propaganda is how skillfully it imbues the idea of jihad not only with traditional notions of honour and virility, but also a strong undercurrent of oppositional, postmodern cool. CVE practitioners can't possibly hope to challenge 
the glamour, energy, and sheer badassery of violent jihad as an ideal, still less the wider emotional resonance of the warrior ethos on which it draws. But they can reasonably hope to subvert ISIS's claim to embody that ideal. What isn't yet clear is at precisely whom CVE programmes should be targeted, how their countermessaging should be framed and delivered, and, crucially, by whom. Vague references to those "at risk of" or "vulnerable to" radicalisation, and to "credible voices" who can offer alternatives, do little to help in this regard. Challenging ISIS's bona fides as the true inheritor of jihad is also fraught with peril, in that it may play into the hands of other jihadist groups who profess that mantle. The bigger challenge-as Alberto Fernandez, the former coordinator of the U.S. State Department's Center for Strategic Counterterrorism Communications, noted when I interviewed him earlier this year-is how to create a counter-narrative that is not merely negative but boldly affirmative, offering a vision that is just as exhilarating and seductive as that of the jihadists. "The positive narrative," he said, "is always more powerful, especially if it involves dressing in black like a ninja, having a cool flag, being on television, and fighting for your people." The problem for CVE is that in an ironic age in which few "grand narratives" remain, no one-except perhaps for the jihadists and their supporters-really knows what that narrative is anymore.

In modern democratic countries, Islamic fundamentalists have unlimited use of communications, telecommunications, transport and services. In a democracy, it is more difficult to organise effective action against the threats of a terrorist. These elements make the democratic states particularly vulnerable to possible attacks from Islamic extremists. Broad civil rights, a representative system of government, and freedom of the population create the conditions which make it possible to try to force a certain behaviour from the authorities, via a direct impact on the psychological state of society.

Communities that are threatened in varying degrees by terrorist activities are increasingly demanding through demonstrations, the media and their representatives, measures aimed at eliminating the threat from terrorists. More importantly, no one wants to take the fight to them or conduct armed interventions, or accept the demands of extremists. Expressing such consent may also lead to irreversible consequences for the whole world. An example of this approach to Islamist extremists is the election campaign in Spain in 2004. 
Two days before the Spanish elections, the Moroccan Al-Qaeda group carried out the bloody bombings in Madrid. Shortly after these, messages appeared on web portals about the next planned attacks in Spain, if the government does not withdraw its contingents from Iraq.

"We are in a battle, and more than half of this battle is taking place in the battlefield of the media," Ayman al-Zawahiri, then al-Qaeda's second-in-command, purportedly wrote in a 2005 letter to Abu Musab al-Zarqawi, the Jordanian who led al-Qaeda in Iraq at the time. The previous year, Zarqawi's network, originally known as Tawhid and Jihad, had publicly released more than 10 beheading videos, including a video believed to show Zarqawi himself beheading the American businessman Nicholas Berg. This was bad PR, Zawahiri cautioned his hotheaded field commander, and risked alienating Muslims.

"Media is more than half the battle" also happens to be the motto of the U.S. State Department's Center for Strategic Counterterrorism Communications (CSCC), founded in 2010 as the world's first government-sponsored enterprise not run by an intelligence agency to counter online jihadist propaganda.

\section{Bibliography}

Al-Zaky A., (2009, March-): @AhmadAlZ, https://twitter.com/ahmadalz

Bunt G. R., iMuslims: Rewiring the House of Islam. (Islamic Civilization and Muslim Networks), Chapel Hill, The University of North Carolina Press, 2009.

Byman D., Breaking the Bonds between Al-Qa'ida and Its Affiliate Organizations, Brookings, 2012 https://www.brookings.edu/ /media/research/files/papers/2012/7/ alqaida\%20terrorism\%20byman/alqaida\%20terrorism\%20byman.pdf.

Cyberterrorism Project, The Cyberterrorism Project Site, http://www.cyberterrorismproject.org, 2012

Chuvlov M., , How an arrest in Iraq revealed Isis's \$2bn jihadist network, The Guardian, 15 June 2014

http://www.theguardian. com/world/2014/jun/15/iraq-isis-arrest-jihadists-wealth-power Harper T., Alan Henning: Al-Qaeda appealed to Isis to release British aid worker following kidnap, The Independent, April 22, 2015 http://www.independent.co.uk/news/world/ middle-east/alan-henning-alqaeda-appealed-to-isis-to-release-british-aid-workerfollowing-kidnap-9734598.html. 
Holmer G., Countering Violent Extremism: A Peace Building Perspective. USIP, 29 August, 2013.

Price E., Literature on Terrorism, Media, Propaganda E Cyber-Terrorism. Perspectives on Terrorism, 6(1), March 2012. http://www.terrorismanalysts.com/pt/index.php/pot/ article/view/price-literature-terrorism-media

Sherlock R., Spencer R., Senior al-Qaeda jihadist speaks out in defence of Peter Kassig, The Telegraph, October 22, 2014 http://www.telegraph.co.uk/news/worldnews/islamicstate/11181229/Senior-al-Qaeda-jihadist-speaks-out-in-defence-of-Peter-Kassig.html.

Signorielli N., Gerbner G., Violence and Terror in the Mass Media: An Annotated Bibliography, Bibliographies and Indexes in Sociology,

13. Greenwood Press, New York, 1988.

Williams J. R., particularly ISIS vs. Al Qaeda: Jihadism's Global Civil War, The National Interest, February/March 2015. http://nationalinterest.org/feature/isis-vs-al-qaedajihadism\%E2\%80\%99s-global-civil-war-12304.

Zelin A. Y., Jihadology, 2010. URL: http://jihadology.net

\section{Websites}

http://www.dailymail.co.uk/news/article-2937641/ISIS-fighters-

distributing-video-game-allows-players-play-role-Islamist-kill-Westerners. htmloot Obama,

Captain IS, Go to Syria

http://www.defenseone.com/threats/2015/12/call-jihad-isis-turns-video-games-

hollywood-reach-recruits/124709/

https://www.brookings.edu/blog/techtank/2015/09/24/on-social-media-isis-uses-

modern-cultural-images-to-spread-anti-modern-values/

https://ent.siteintelgroup.com/Dark-Web-and-Cyber-Security/pro-is-telegram-channel-

shares-guides-for-falsifying-id-to-reactivate-facebook-accounts.html

https://www.rt.com/news/188788-isis-video-game-youtube/

http://www.news.com.au/technology/home-entertainment/gaming/game-reviews/

islamic-state-adapt-grand-theft-auto-game-into-virtual-jihad-recruitment-drive-

for-kids/news-story/c3b3e4ff965833007b824978a5cadee9

http://www.sploder.com/games/members/29275/play/the-jihad/

https://boardgamegeek.com/thread/1645241/jihadist-bot-plot-question

http://www.clarionproject.org/news/islamic-state-isis-isil-propaganda-magazine-dabiq https://azelin.files.wordpress.com/2016/07/the-islamic-state-e2809cdacc84biq-

magazine-1522.pdf

ISIS jihadists declare 'Islamic caliphate', Al Arabiya, June 29, 2014, http://english.alarabiya. net/en/News/2014/06/29/ISIS-jihadists-declare-caliphate-.html.

'Islamic State now controls resources and territory unmatched in history of extremist organisations, Washington Post 
http://www.washingtonpost.com/news/morningmix/wp/2014/08/04/islamic-state-nowcontrolsresources-and-territory-unmatched-in-history-of-extremistorganizations/ SRSG Bangura and SRSG Mladenov gravely concerned by reports of sexual violence against internally displaced persons, 13 August, 2014,

United Nations Iraq: http://www.uniraq.org/index.

php?option=com_k2\&view=item \&id=2373:srsg-bangura-and-srsgmladenov gravely-concerned-by-reports-of-sexual-violence-againstinternally-displacedpersons\&Itemid=605\&lang=en 